\title{
Permasalahan Pelaksanaan Pelayanan Administrasi Terpadu Kecamatan (Paten) Di Kota Padang
}

\author{
The Problems Of Integrated Administration Service Districts In Padang
}

\author{
Afriyanni \\ Badan Penelitian dan Pengembangan Provinsi Sumatera Barat \\ Jln. Jenderal Sudirman No.51 Padang \\ Telp. (0751) 8956679 Hp.085228559909 \\ E-mail: afriyannisubhan@ymail.com
}

Naskah Masuk : 09-04-2018Ｎaskah Diterima : 23-04-2018Ｎ Naskah Disetujui : 04-06-2018

\begin{abstract}
PATEN is a new public management centered in the sub-district to improve the quality and bring the service closer to the community. Since Regulatory of minister Affair number 4 in 2010 was declared. The Implementation of PATEN in Indonesia nowdays reach 15 percent. This research aims to identify the problem of impelementation PATEN in Pilot district projects in Padang in order to provide recommendation for PATEN implementation. This study used descriptive qualitative research through observation, documentation and interview in collecting data. The result showed that there are a number of obstacles in the implementation of PATEN namely the delegation of authority, procedures, human resources, limited facilities and infrastructure. For That, it is amust for the Local Government to handle those problems.
\end{abstract}

Keywords: PATEN, public management, Sub District

\section{Abstrak}

PATEN merupakan suatu new public management yang dipusatkan di kecamatan untuk meningkatkan kualitas dan mendekatkan pelayanan kepada masyarakat. Sejak ditetapkan dengan Permendagri Nomor 4 Tahun 2010, pelaksanaan PATEN di Indonesia baru mencapai lebih kurang 15 persen. Penelitian ini bertujuan untuk mengkaji permasalahan pelaksanaan PATEN pada Kecamatan Pilot Project di Kota Padang dan selanjutnya memberikan rekomendasi untuk peningkatan kualitas pelaksanaan PATEN. Penelitian ini menggunakan metode deskriptif kualitatif melalui pengumpulan data secara observasi, studi dokumentasi dan wawancara. Hasil penelitian menunjukkan bahwa tujuan pelaksanaan PATEN pada kecamatan pilot project belum tercapai karena adanya permasalahan pelimpahan kewenangan, keterbatasan SDM serta keterbatasan sarana dan prasarana.

Kata Kunci: PATEN, pelayanan publik, reformasi

\section{PENDAHULUAN}

Pelayanan publik merupakan bagian dari tugas pokok organisasi pemerintahan termasuk pemerintahan daerah. Menurut Wasistiono, 2011 pelayanan adalah pemberian jasa baik oleh pemerintah, pihak swasta atas nama pemerintah ataupun pihak swasta kepada masyarakat dengan atau tanpa pembayaran guna memenuhi kebutuhan dan kepentingan masyarakat. Dengan demikian pemerintah berkewajiban memberikan pelayanan publik yang berkualitas sebaliknya masyarakat memiliki hak untuk memperoleh pelayanan publik yang berkualitas dari pemerintah. Faktanya kualitas pelayanan publik di Indonesia masih perlu mendapat perhatian serius.

Hasil laporan tahunan Ombudsman Republik Indonesia Tahun 2014 menunjukkan Jumlah Laporan Masyarakat 
terhadap pelayanan publik setiap tahun cenderung meningkat. Pada tahun 2010, pengaduan masyarakat yang diterima oleh Ombudsman RI berjumlah 1.137 laporan meningkat menjadi 6.677 laporan. Berdasarkan klasifikasi terlapor, pemerintah daerah paling banyak dilaporkan $(43,24 \%)$ menyusul kepolisian (12,76\%), Instansi Pemerintah/kementerian $\quad(9,54 \%) \quad$ serta instansi lainnya $(34,46 \%)$. Jika dilihat dari substansi mal administrainya maka secara berurutan paling banyak dilaporkan masyarakat adalah penundaan berlarut $(25,64 \%)$, penyimpangan prosedur $(20,67 \%)$, tidak memberikan pelayanan $(14,09 \%)$ dan penyalahgunaan wewenang $(11,65 \%)$.

Berdasarkan data tersebut pelayanan yang dilaksanakan oleh pemerintah daerah paling banyak disorot dan jika dilihat dari substansi pelaporan maka sistem, prosedur, metode dan personal pelayanan perlu ditingkatkan untuk menghasilkan pelayanan yang berkualitas. Usaha ini penting dilakukan karena pelayanan publik bukan merupakan persoalan administratif semata tetapi juga mencakup persoalan yang lebih mendasar yaitu pemenuhan kebutuhan pelanggan/masyarakat.

Salah satu upaya yang dilakukan oleh pemerintah untuk mengatasi permasalahan tersebut adalah melalui peningkatan pelayanan publik di kecamatan dalam bentuk Pelayanan Administrasi Terpadu Kecamatan (PATEN). Berdasarkan Peraturan Menteri Dalam Negeri Nomor 4 Tahun 2010 tentang
Pedoman Pelayanan Administrasi Terpadu Kecamatan merupakan suatu new public management yang dipusatkan di kecamatan untuk meningkatkan kualitas dan mendekatkan pelayanan kepada masyarakat. Fungsi kecamatan sebagai pusat pelayanan masyarakat menjadi relevan jika dilihat dari segi kedekatan jarak, kecepatan waktu dan kualitas pelayanan yang diberikan. Hal ini sejalan dengan fungsi kecamatan sebagaimana diamanatkan dalam Peraturan Pemerintah Nomor 19 Tahun 2008 tentang Kecamatan yang menyatakan bahwa camat bertugas melaksanakan pelayanan kepada masyarakat di kecamatan dan melakukan percepatan pencapaian standar minimal di wilayahnya. Fungsi PATEN lainnya yang tidak kalah penting menurut Miranti 2015 adalah memperkuat eksistensi badan/kantor/dinas pelayanan terpadu satu pintu dalam mendukung iklim investasi.

Konsep pelaksanaan PATEN diatur dalam Peraturan Menteri Dalam Negeri Nomor 4 Tahun 2010 dan Keputusan Menteri Dalam Negeri Nomor 138-270 tahun 2010 tentang juknis PATEN. Berdasarkan peraturan tersebut kecamatan diseluruh Indonesia harus menyelenggarakan PATEN paling lambat 5 (lima) tahun sejak ditetapkan namun sampai Februari 2015, tercatat baru 1005 kecamatan yang melaksanakan PATEN atau lebih kurang 15 persen dari jumlah seluruh kecamatan di Indonesia (Kemendagri, 2015). 
Berdasarkan Permendagri Nomor 4 Tahun 2010 tentang PATEN, terdapat 3 persyaratan yang harus dipenuhi kecamatan untuk ditetapkan sebagai kecamatan PATEN. Persyaratan tersebut yaitu substantif, administratif dan teknis. Persyaratan substantif berupa pendelegasian sebagian kewenangan walikota kepada camat baik perizinan maupun non perizinan. Secara administratif, kecamatan pelaksana PATEN harus memiliki standar pelayanan dan uraian tupoksi yang jelas. Secara teknis kecamatan pelaksana PATEN harus memiliki sarana prasarana dan pelaksana teknis untuk mendukung pelayanan.

Faktanya sebagian besar kecamatan belum memenuhi ketiga persyaratan tersebut sebagaimana beberapa hasil penelitian yang menunjukkan penyebab belum efektif dan efisiennya pelayanan publik melalui PATEN antara lain disebabkan oleh regulasi (Dewi, 2014) SDM (Dewi, 2014 dan Eko dkk, 2015), prosedur birokrasi (Eko dkk, 2015), sarana prasarana pendukung (Eko, 2015 dan Lanti, 2015) serta pemahaman masyarakat terhadap program (Lanti, 2015).

Kota Padang merupakan salah satu kota di Provinsi Sumatera Barat yang berkomitmen dalam pelaksanaan PATEN. Pelaksanaan PATEN di Kota Padang diawali dengan pelaksanaan Pilot Project penyelenggra PATEN di Kecamatan Kuranji dan Pauh yang telah dilaunching oleh Gubernur Sumatera Barat pada tanggal 17 Desember 2014. Selama 1 (satu) tahun pelaksanaan PATEN di kedua kecamatan pilot project masih terdapat beberapa permasalahan yang menyebabkan pelaksanaan PATEN belum optimal. Berdasarkan observasi awal beberapa temuan yang menghambat pelaksanaan PATEN terkait dengan keterbatasan anggaran dan SDM serta pelimpahan kewenangan kepada kecamatan khususnya kewenangan di bidang perizinan yang sebelumnya berada di SKPD teknis terkait.

Evaluasi pelaksanaan PATEN pada kedua kecamatan pilot project tersebut perlu dilakukan sebagai bahan penyempurnaan pelaksanaan PATEN yang akan dilaksanakan secara bertahap pada sembilan kecamatan lainnya. Oleh karena itu penelitian ini penting dilakukan untuk memberikan gambaran pelaksanaan dan mengidentifikasi permasalahan pelaksanaan PATEN pada kecamatan pilot project dalam rangka merumuskan rekomendasi kebijakan untuk penyempurnaan pelaksanaan PATEN secara bertahap di seluruh kecamatan di Kota Padang.

\section{METODOLOGI}

Lokasi penelitian ini adalah Kecamatan Kuranji dan Kecamatan Pauh Kota Padang Provinsi Sumatera Barat. Alasan pemilihan lokasi adalah kedua kecamatan tersebut merupakan kecamatan yang ditetapkan sebagai pilot project penyelenggaraan PATEN di Kota Padang berdasarkan Surat Keputusan Walikota 
Nomor 335 Tahun 2014 tentang Kecamatan sebagai Penyelenggara Administrasi Terpadu Kecamatan (PATEN).

Penelitian ini menggunakan pendekatan penelitian deskriptif kualitatif yaitu penelitian yang mendeskripsikan fenomena yang ada dilapangan secara luas dan realitas tentang Pelaksanaan PATEN di Kota Padang. Pengambilan sampel dilakukan secara purposive yaitu pemilihan sampel dengan tujuan untuk memperoleh informasi terkait pelaksanaan PATEN. Untuk memperoleh data dilapangan, peneliti menggunakan teknik data melalui observasi non partisipatif, studi dokumentasi/kepustakaan dan wawancara. Obervasi non partisipatif dilakukan dengan melakukan pengamatan terhadap objek yang diteliti tanpa terlibat langsung dengan objek tersebut. Peneliti melakukan pengamatan secara langsung terhadap proses/mekanisme pelaksanaan PATEN di loket PATEN.

Untuk memperkuat observasi, peneliti melakukan wawancara dengan pejabat terkait

pelaksana PATEN, yaitu Camat, Sekcam, Kasi Pelayanan dan Perizinan, pejabat dari SKPD terkait dan masyarakat yang datang ke loket PATEN. Studi dokumentasi dilakukan dengan menelaah peraturanperaturan, dokumen - dokumen perencanaan, panduan/ pedoman PATEN, serta data/literature lain yang berhubungan dengan pelaksanaan PATEN.

Teknik pengumpulan data yang digunakan adalah triangulasi dari observasi non partisipatif, wawancara dan dokumentasi. Analisis data menggunakan model interaktif dari Miles dan Huberman yang diterjemahkan oleh Sugiyono, 2011. Analisis model interaktif dari Miles dan Huberman terdiri dari empat tahap, yaitu pengumpulan data, reduksi data, penyajian data, dan kesimpulan.

Pengumpulan data merupakan tahap awal dalam analisis yaitu dengan cara memperoleh data dari observasi, wawancara, dan dokumentasi. Reduksi data berarti merangkum, memilih hal-hal yang pokok, memfokuskan pada hal-hal yang penting, dan membuang yang tidak perlu. Penyajiian data dalam penelitian kualitatif dilakukan dalam bentuk uraian singkat berupa teks yang bersifat naratif. Tahap akhir dalam analisis yaitu kesimpulan.

\section{HASIL DAN PEMBAHASAN}

\section{Pelaksanaan PATEN di Kota Padang}

Pelaksanaan PATEN di Kota Padang berdasarkan Surat Keputusan Walikota Nomor 335 Tahun 2014 tentang Kecamatan sebagai Pelayanan Administrasi Terpadu Kecamatan. Dalam surat keputusan tersebut ditetapkan Kecamatan Kuranji dan Kecamatan Pauh sebagai kecamatan penyelenggara PATEN. Kedua Kecamatan tersebut dipilih berdasarkan pertimbangan kesiapan SDM, sarana prasarana dan anggaran dalam melaksanakan PATEN. 


\section{Pelimpahan Kewenangan}

Sesuai Pasal 6 Peraturan Menteri Dalam Negeri Nomor 4 Tahun 2010, salah satu persyaratan pelaksanaan PATEN adalah adanya pelimpahan kewenangan ke kecamatan. Pelimpahan kewenangan tersebut akan berjalan efektif dan efisien menurut pendapat George R. Terry, 1986 haruslah memiliki prinsip-prinsip sebagai berikut:

1. Principle of delegation by Results expected.

Pendelegasian kewenangan didasarkan pada hasil yang dapat diperkirakan apakah pelaksanaan kewenangan tersebut semakin efektif atau tidak.

2. Principle of functional definition.

Pendelegasian hendaknya didasarkan pada pertimbangan-pertimbangan fungsional agar pekerjaan atau tugas tertentu dapat dilaksanakan secara lebih efisien dan efektif.

3. Scalar Principle.

Pendelegasian wewenang hendaknya dilakukan berdasarkan hirarki jabatan.

4. Authority Level Principle.

Pendelagasian wewenang dilakukan secara bertahap berdasarkan tingkat kewenangan yang diemban oleh seorang pejabat atau suatu organisasi tertentu.

5. Principle of unity of command.

Pendelegasian kewenangan sebaiknya menekankan adanya kesatuan komando.
6. Principle of absoluteness of responsibility.

Pendelegasian kewenangan hendaknya diimbangi oleh pemberian tanggungjawab sehingga pihak yang member wewenang sebaiknya tidak terlalu ikut campur.

7. Principle of parity of authority and responsibility.

Pendelegasian kewenangan harus diikuti oleh tanggungjawab yang seimbang

Secara substantif Pemerintah Kota Padang telah memiliki landasan hukum pelimpahan kewenangan untuk pelaksanaan PATEN yaitu Peraturan Walikota Padang Nomor 22 Tahun 2014 tentang Pelimpahan sebagian kewenangan Walikota kepada Camat. Pelimpahan yang diberikan disesuaikan dengan tugas pokok dan fungsi kecamatan yaitu memberikan pelayanan umum kepada masyarakat baik pelayanan yang bersifat perizinan maupun non perizinan. Hal ini sesuai dengan prinsip pendelegasian wewenang Geroge R Terry, 1986 yaitu Authority Level Principle yaitu pelimpahan kewenangan yang diberikan kepada kecamatan dilakukan secara bertahap berdasarkan tingkat kewenangan yang diemban oleh suatu organisasi tertentu.

Kewenangan pelayanan perizinan yang diserahkan ke kecamatan yaitu penerbitan IMB dan penerbitan Izin HO. Pelimpahan kewenangan penerbitan IMB telah diatur melalui Perwako Nomor 43 
Tahun 2014 tentang Pelimpahan Kewenangan Penerbitan Izin Mendirikan Bangunan kepada Camat sedangkan pengaturan penerbitan Izin $\mathrm{HO}$ dan retiribusinya belum diatur dalam bentuk peraturan walikota. Berdasarkan Perwako Nomor 43 Tahun 2014, pelimpahan kewenangan penerbitan IMB kepada camat dengan ketentuan:

a. Bangunan baru dengan luas paling tinggi $100 \mathrm{~m}^{2}$ (seratus meter bujursangkar) dan tidak bertingkat yang berada pada ruas jalan lokal primer atau lokal sekunder lebar paling tinggi $12 \mathrm{~m}$; (dikecualikan untuk kompleks perumahan baru yang dibangun oleh pengembang)

b. Mengubah, memperluas atau merenovasi bangunan yang sudah atau belum memiliki IMB dengan luas paling tinggi $100 \mathrm{~m}^{2}$ yang berada pada ruas jalan lokal primer atau lokal sekunder lebar paling tinggo $12 \mathrm{~m}$; dan

c. Untuk bangunan yang sudah berdiri dan belum mempunyai IMB dengan luas bangunan paling tinggi $200 \mathrm{~m}^{2}$ dan tidak berintgkat yang berada pada ruas jalan lokal primer atau lokal sekunder lebar paling tinggi $12 \mathrm{~m}$.

Berdasarkan peraturan tersebut, kecamatan memiliki kewenangan menerbitkan IMB untuk bangunan baru atau renovasi dengan luas bangunan $100 \mathrm{~m}^{2}$ dan tidak bertingkat atau bangunan yang sudah berdiri dengan luas $200 \mathrm{~m}^{2}$ dan tidak bertingkat. Penerbitan IMB tersebut dilakukan setelah mendapatkan Keterangan Rencana Kota - Peruntukan Ruang Kota (KRK-PRK) dari DTRTB Kota Padang terlebih dahulu. Demikian juga dengan kewenangan non perizinan yang dilimpahkan kepada kecamatan seperti rekomendasi, pelayanan KTP, KK dan surat-surat kependudukan lainnya. Untuk pelayanan tersebut, kecamatan hanya berfungsi sebagai perantara karena pelayanannya masih berlanjut ke SKPD lain, yaitu Dinas Kependudukan dan Pencatatan Sipil. Hal ini menyebabkan pelayanan menjadi tidak efisien karena pelayanan masih tergantung pada SKPD lain sehingga sulit memberikan kepastian waktu kepada masyarakat.

\section{Sumber Daya Manusia}

Sumberdaya memegang peranan penting dalam pelaksanaan suatu program. Oleh karena itu menurut George Edward III (1980) keberhasilan pelaksanaan program sangat tergantung pada kecukupan sumberdaya yang tersedia atau sejauh mana sumberdaya yang ada dapat mendukung implementasi program sesuai tuntutan kebutuhan yang ada. Secara kuantitas SDM pelaksana PATEN pada dua kecamatan masih terbatas namun keterbatasan tersebut diatasi dengan merekrut tenaga honorer atau tenaga sukarela sebagai pelaksana teknis PATEN. Hal tersebut tentu saja tidak sesuai dengan amanat Pasal 11 ayat 3 yang menyebutkan bahwa pelaksana teknis PATEN adalah PNS 
di kecamatan.

Tabel 1 Pelaksana Teknis PATEN Kecamatan Pauh

\begin{tabular}{|c|c|c|c|c|c|}
\hline \multirow[t]{2}{*}{ No } & \multirow{2}{*}{\multicolumn{2}{|c|}{ Jabatan Teknis PATEN }} & \multicolumn{3}{|c|}{ Status Kepegawaian } \\
\hline & & & PNS & Non PNS & Jlh \\
\hline 1 & Penanggung Jawab & & 1 & & 1 \\
\hline 2 & Kesekretariatan & & 3 & & 3 \\
\hline 3 & Operator & & 2 & 1 & 3 \\
\hline 4 & Petugas Penerima Berkas & & 1 & & 1 \\
\hline 5 & $\begin{array}{l}\text { Penyerahan Dokumen } \\
\text { Perizinan }\end{array}$ & Akhir & & 1 & 1 \\
\hline 6 & $\begin{array}{l}\text { Penyerahan Dokumen } \\
\text { non Perizinan }\end{array}$ & Akhir & & 1 & 1 \\
\hline & Jumlah & & 7 & 3 & 10 \\
\hline
\end{tabular}

Sumber: Data diolah tahun 2015

Apabila dilihat dari jumlah petugas pelaksana teknis, maka petugas pelaksana di Kecamatan Kuranji lebih besar dibandingkan Kecamatan Pauh. Perbedaan tersebut disesuaikan dengan SDM dan anggaran yang ada serta jumlah penduduk yang dilayani. Kecamatan Kuranji dengan jumlah penduduk 130.916 orang lebih besar dibandingkan dengan jumlah penduduk Kecamatan Pauh yang hanya berjumlah 61.755 orang.

Jika dilihat dari status kepegawaian petugas pelaksana teknis, komposisi Petugas pelaksana Teknis PATEN di Kecamatan Pauh yang berstatus PNS lebih besar dari petugas Non PNS (lihat Tabel 1). Hal tersebut berbeda dengan komposisi petugas pelaksana PATEN di Kecamatan Kuranji yang hampir berimbang antara petugas yang berstatus PNS dan Non PNS (lihat Tabel 2).

\section{Masing-masing}

kecamatan

menempatkan pegawai non PNS pada jabatan teknis yang memiliki tanggungjawab yang tidak begitu besar jika dibandingkan petugas PNS. Petugas pelaksana PATEN non PNS di Kecamatan Pauh ditempatkan sebagai operator dan petugas penyerahan dokumen akhir sedangkan di Kecamatan Kuranji Petugas Non PNS tersebut ditempatkan sebagai petugas informasi, petugas loket penerima berkas, petugas loket penyerahan berkas dan operator komputer dan Tim survey

Tabel 2 Pelaksana Teknis PATEN Kecamatan Kuranji (SK Nomor 71 Tahun 2015)

\begin{tabular}{|c|c|c|c|c|}
\hline \multirow[t]{2}{*}{ No } & \multirow[t]{2}{*}{ Jabatan Teknis PATEN } & \multicolumn{3}{|c|}{ Status Kepegawaian } \\
\hline & & PNS & Non PNS & Jlh \\
\hline 1 & $\begin{array}{ll}\text { Penanggung } & \text { Jawab } \\
\text { Kesekretariatan } & \end{array}$ & 1 & & 1 \\
\hline 2 & Petugas Informasi & & 1 & 1 \\
\hline 3 & Petugas Loket Penerima Berkas & 1 & 1 & 2 \\
\hline 4 & Petugas Operator Komputer & & 1 & 1 \\
\hline 5 & $\begin{array}{l}\text { Petugas Loket Penyerahan } \\
\text { Berkas Akhir }\end{array}$ & & 1 & 1 \\
\hline
\end{tabular}




\begin{tabular}{lllll}
\hline 6 & Petugas Caraka Berkas & 1 & & 1 \\
7 & Petugas Caraka Dokumen & 1 & 1 & 1 \\
8 & Tim Survey Lapangan & 3 & $\mathbf{5}$ & $\mathbf{1 2}$ \\
\hline
\end{tabular}

Sumber: Data diolah tahun 2015

Secara kualitas, petugas pelaksana

demikian untuk menjawab tuntutan

teknis PATEN di kedua kecamatan pilot pelayanan masyarakat yang semakin project cukup baik. Petugas pelaksana telah kompleks petugas pelaksana perlu memiliki pendidikan yang tinggi, yaitu diberikan bimbingan dan pelatihan.

SMA dan Perguruan Tinggi namun

Tabel 3. Pelaksana teknis PATEN menurut tingkat pendidikan

\begin{tabular}{l|l|l|l|l|l}
\hline \multirow{2}{*}{ No } & Kecamatan & \multicolumn{4}{|c}{ Tingkat Pendidikan } \\
\cline { 2 - 6 } & & SD & SMP & SMA & PT \\
\hline 1 & Kuranji & - & - & 4 & 8 \\
2 & Pauh & - & - & 2 & 8 \\
\hline
\end{tabular}

Sumber: data diolah, 2015

Berdasarkan hasil wawancara dengan pejabat terkait diketahui bahwa peningkatan SDM kecamatan dilakukan secara internal maupun eksternal. Secara internal, kecamatan melaksanakan sosialisasi tentang PATEN di lingkungan kecamatan, memberikan bimbingan teknis tentang etika pelayanan dan mengirimkan petugas pelaksana mengikuti kegiatan yang mendukung pelaksanaan PATEN di kecamatan.

Secara eksternal, Bagian Pemerintahan selaku instansi pembina kecamatan telah melakukan Bimtek bagi petugas pelaksana teknis PATEN dalam hal penyusunan visi, misi pelayanan dan tupoksi. Selain itu Bagian Organisasi juga melakukan fasilitasi terhadap penyusunan Standar Operasional Prosedur (SOP) dan Standar Pelayanan Minimal (SPM) pelayanan kecamatan.

Hasil observasi menunjukkan pelaksana teknis kecamatan telah mengikuti Standar Operasional Prosedur Pelayanan yang sudah ditetapkan. Pelaksana teknis PATEN kecamatan pilot project bertanggung jawab terhadap pencapaian tujuan PATEN yaitu memberikan pelayanan yang dibutuhkan masyarakat. Untuk meningkatkan semangat kerja dari pelaksana teknis PATEN, camat telah berupaya untuk mengusulkan insentif namun belum berhasil (Hasil wawancara dengan sekcam tanggal 21Oktober 2015). Sarana Prasarana

Sarana Prasarana dalam penelitian ini ditinjau dari loket pelayanan dan kondisi kantor. Dari hasil observasi lapangan diketahui bahwa ruang pelayanan PATEN pada kecamatan pilot 
project (lihat Foto 1 dan 2) menyesuaikan dengan kondisi kantor kecamatan sehingga terdapat perbedaan yang jelas tampilan ruang pelayanan antara kedua kecamatan pilot project. Kondisi kantor kecamatan Pauh yang tidak begitu luas, ditempatkan 3 loket pelayanan, yaitu penerima dan penyerahan berkas izin dan non izin, serta loket informasi. Sementara pada kecamatan kuranji karena terdiri dari 3 lantai, ruang pelayanan khusus berada pada lantai 1. Pada ruang tersebut terdapat loket penerima berkas, penyerahan berkas, loket informasi dan loket jaga, ruang Selain itu dilengkapi juga dengan fasilitas pendukung, yaitu: ruang pameran produk UKM, perpustakaan, ruang poliklinik dan laktasi, ruang perekaman EKTP dan arena bermain anak, mushalla dan toilet.

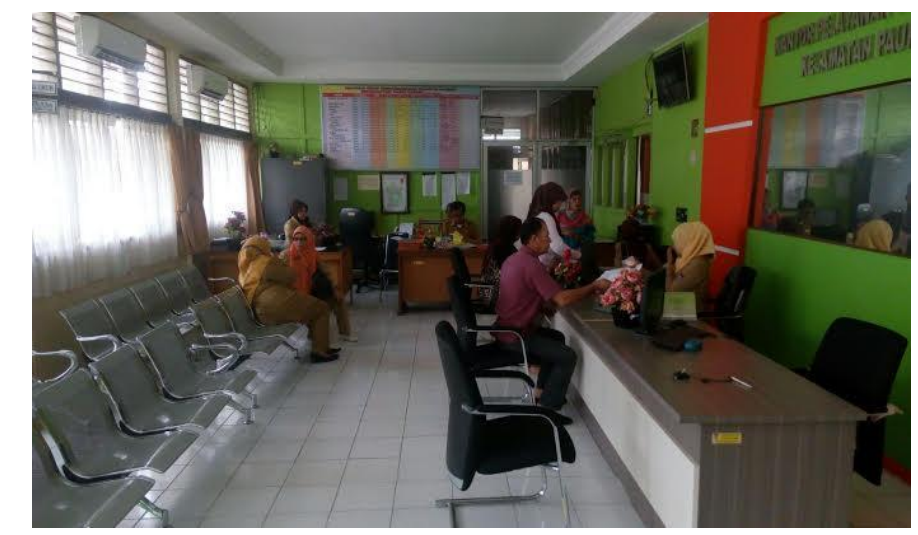

Gambar 1. Suasana pada Loket Pelayanan PATEN Kecamatan Pauh

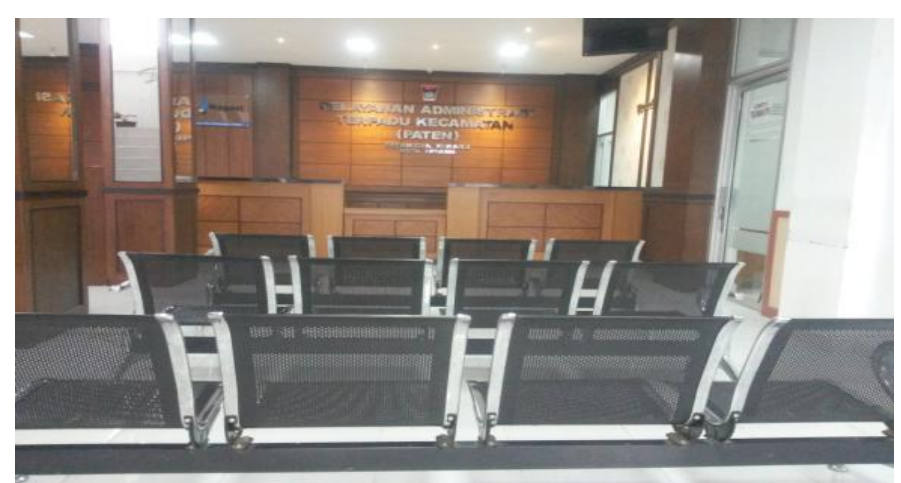

Gambar 2. Loket Pelayanan PATEN Kecamatan Kuranji

Pada ruang pelayanan, terdapat spanduk berisi visi, misi, tujuan dan prosedur pelayanan sebagai media sosialisasi pelaksanaan PATEN kepada masyarakat. Pemasangan papan alur pelayanan juga dipasang pada dinding untuk menginformasikan kepada masyarakat proses yang dilalui pada saat membutuhkan pelayanan. Adanya informasi tentang SOP dan SPM pada ruang pelayanan diharapkan dapat memberikan kepastian terhadap persyaratan, waktu, biaya, proses dan penanggungjawab pelayanan sehingga memberikan kepuasan masyarakat terhadap 
kualitas pelayanan.

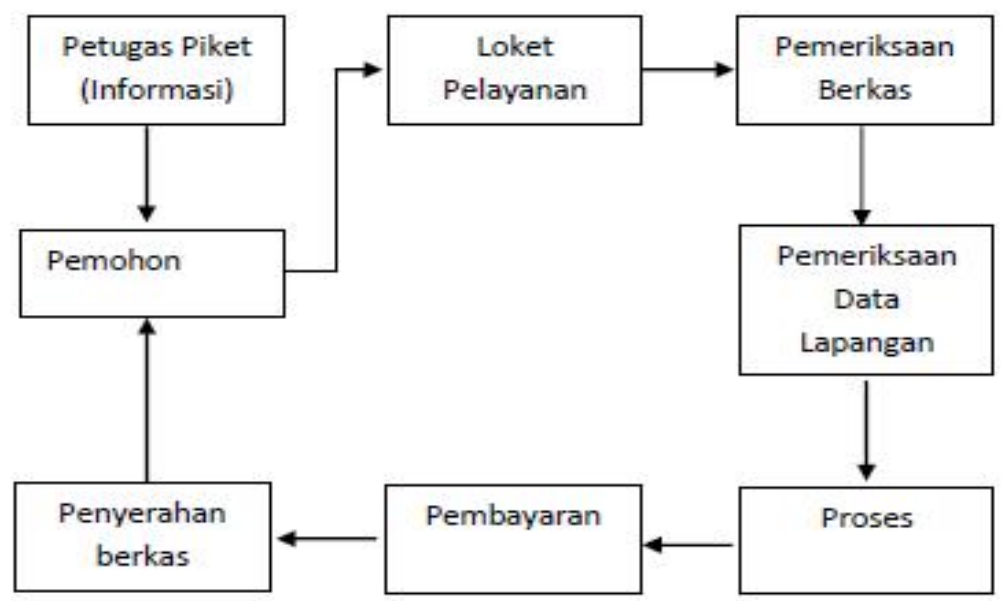

Gambar 3. Mekanisme Pelayanan PATEN

\section{Anggaran}

Pelaksanaan PATEN pada kecamatan pilot Project dibebankan pada Anggaran Pendapatan dan Belanja Daerah (APBD) Kota Padang pada kegiatan Penyelenggaraan Pilot Project Pelayanan administrasi Terpadu Kecamatan (PATEN) sebagaimana dilihat pada tabel 4. Anggaran PATEN disesuaikan dengan kebutuhan kecamatan. Namun demikian perlu diinventarisir kebutuhan sarana PATEN dan ditetapkan standarisasinya untuk pelaksanaan PATEN pada kecamatan lainnya.

Tabel 4. Anggaran pelaksanaan PATEN pada kecamatan pilot project

\begin{tabular}{|c|c|c|c|}
\hline \multirow[t]{2}{*}{ Kecamatan } & \multicolumn{2}{|c|}{ Tahun (ribu) } & \multirow[t]{2}{*}{ Jumlah (ribu) } \\
\hline & 2014 & 2015 & \\
\hline Kuranji & 116.200 & 87.537 & 203.737 \\
\hline Pauh & 122.600 & 120.00 & 242.600 \\
\hline
\end{tabular}

Sumber: Bappeda Kota Padang, 2015

Permasalahan Pelaksanaan PATEN di Administrasi Terpadu Kecamatan,

\section{Kota Padang}

Berdasarkan gambaran umum pelaksanaan PATEN pada kecamatan Pilot Project diketahui terdapat permasalahan baik substantif, administratif, maupun teknis.

\section{Permasalahan Substantif}

Sesuai Pasal 6 Permendagri Nomor 4 Tahun 2010 tentang Pedoman Pelayanan persayaratan substantif dalam pelaksanaan PATEN adalah pelimpahan kewenangan. Merujuk pendapat George R Terry, 1980 efektivitas pelimpahan kewenangan sebaiknya menekankan adanya kesatuan komando. Hasil penelitian menunjukkan pelaksanaan pelimpahan kewenangan tersebut belum optimal karena proses 
pelayanan tersebut tidak selesai di kecamatan namun masih tergantung atau dilanjutkan ke SKPD terkait. Dengan demikian kecamatan tidak dapat memberikan kepastian pelayanan kepada masyarakat. Hasil wawancara menunjukkan pelimpahan sebagian kewenangan walikota kepada camat belum sepenuhnya didukung dengan peraturan yang bersifat teknis operasional sehingga terdapat kewenangan perizinan yang belum terlaksana di kecamatan. Hal tersebut menyebabkan upaya untuk menjadikan kecamatan sebagai simpul pelayanan (front office) PTSP/BPMP2T belum terwujud.

Berdasarkan hasil wawancara dengan Kasubag pembinaan wilayah Bagian Pemerintahan Setda Kota Padang terungkap bahwa SKPD yang melimpahkan kewenangannya kepada kecamatan "terkesan setengah hati" karena tidak diikuti dengan peraturan, prosedur atau pelatihan bagi SDM yang melaksanakan kewenangan tersebut. Hal ini terlihat pada proses pengurusan IMB, pembuatan Keterangan Rencana Kota (KRK) dan Peruntukan Rencana Kota (PRK) sebagai syarat pengurusan izin masih melalui Dinas Tata Ruang dan Tata Bangunan dan Permukiman sehingga membutuhkan waktu yang lama. Akibatnya masyarakat mengurus langsung ke SKPD terkait perizinannya.

$$
\text { Dari aspek pelimpahan }
$$
kewenangan, masih terdapat tarik menarik kepentingan antara SKPD yang melimpahkan kewenangannya dengan kecamatan. Meskipun secara legalitas kecamatan diberikan kewenangan untuk melakukan pengurusan IMB namun masih terdapat proses perizinannya yang harus melalui dinas teknis terkait. Demikian juga halnya dengan pelayanan non perizinan, pengurusan KTP dan KK serta dokumen kependudukan lainnya belum tuntas di kecamatan masih tergantung pada Dinas Kependudukan dan Pencatatan Sipil. Hal ini menyebabkan pelimpahan kewenangan tersebut menjadi tidak efektif dan efisien.

Hal diatas sesuai dengan pendapat Edward III, 1980 yang menyebutkan bahwa struktur birokrasi yang tidak efisien dapat menyebabkan implementasi kebijakan masih belum efektif. Struktur birokrasi mencakup struktur organisasi, pembagian kewenangan, hubungan antara unit-unit organisasi yang ada dalam organisasi, dan hubungan antar organisasi .

\section{Permasalahan Administratif}

Dari aspek standar pelayanan, kecamatan pilot project PATEN telah memiliki SOP, SPM serta uraian tugas yang jelas sehingga terdapat kejelasan dan kepastian prosedur, biaya, waktu dan kejelasan penanggung jawab pelayanan. Namun untuk proses perizinan tertentu harus melalui SKPD terkait sehingga waktu pelayanan tidak dapat dipastikan. Hal tersebut terungkap 
berdasarkan wawancara dengan pejabat pelaksana teknis PATEN Kecamatan Pauh.

“...kami hanya dapat memberikan prosedur pelayanan pada kecamatan namun terkait prosedur pada dinas teknis misalnya IMB dan Dinas Kependudukan dan Pencatatan Sipil tidak dapat kami pastikan"

(Hasil wawancara tanggal 20

Oktober 2015)

Hal ini menunjukkan bahwa meskipun telah ada kepastian atau kejelasan prosedur dan waktu layanan pada tingkat kecamatan namun karena tanggungjawab pelaksanaan kebijakan PATEN terfragmentasi kepada beberapa SKPD, pelaksanaan kebijakan tersebut tidak berjalan efektiv karena kurangnya koordinasi. Hal ini sejalan dengan yang diungkapkan oleh Edward III $^{14}$ yang menjelaskan bahwa :

"struktur birokrasi yang
terfragmentasi (terpecah-pecah atau
tersebar) dapat meningkatkan
gagalnya komunikasi, karena
kesempatan untuk instruksinya
terdistorsi sangatbesar".

\section{Permasalahan Teknis}

Keterbatasan Sumber Daya Manusia juga menghambat pelaksanaan PATEN.

Berdasarkan Pasal 11 ayat

Permendagri Nomor 4 tahun 2010 yang mensyaratkan pelaksana teknis adalah PNS belum dapat dipenuhi oleh kecamatan pilot project, karena terbatasnya jumlah personil kecamatan. Untuk memenuhi kebutuhan SDMnya kecamatan merekrut atau memberdayakan tenaga honorer atau tenaga kontrak yang ada. Kualitas SDM yang rendah, khususnya untuk pekerjaan yang bersifat teknis, menjadi salah satu faktor yang menjadi alasan bagi Dinas teknis untuk tidak melimpahkan kewenangannya sepenuhnya kepada kecamatan.

\section{PENUTUP}

\section{Kesimpulan}

Pelaksanaan PATEN pada kedua kecamatan pilot project telah memiliki landasan hukum berupa pelimpahan kewenangan dari walikota kepada kecamatan, sarana dan prasarana layanan sudah cukup baik namun masih terbatas SDM sebagai pelaksana teknis masih terbatas. Beberapa permasalahan pelaksanaan PATEN pada kedua kecamatan pilot project, yaitu:

1. Implementasi pelimpahan kewenangan kepada camat belum diikuti dengan peraturan atau kebijakan pendukung lainnya sehingga proses pelayanan tidak berjalan efektif.

2. Belum memadainya kualitas dan kuantitas pelaksana teknis pelayanan PATEN.

3. Belum ada standar baku terhadap sarana dan prasarana, SPM, SOP maupun uraian tugas pelaksana PATEN.

$\begin{array}{llrr}\text { 4. } & \text { Monitoring } & \text { dan } & \text { Evaluasi } \\ \text { pelaksanaan } & \text { PATEN } & \text { belum }\end{array}$


terlaksana dengan baik

\section{Rekomendasi}

Berdasarkan hasil analisis terhadap permasalahan pelaksanaan PATEN pada dua kecamatan Pilot Project di Kota Padang, direkomendasikan hal-hal sebagai berikut :

1. Koordinasi antar instansi terkait khususnya kecamatan dengan SKPD yang melimpahkan kewenangannya perlu segera dibenahi dengan menetapkan peraturan teknis operasional.

2. Perlu dilakukan penguatan terhadap kualitas dan kuantitas pelaksana teknis PATEN.

3. Untuk kepentingan efisiensi anggaran perlu disusun SOP Sarpras PATEN sesuai dengan kebutuhan kecamatan pelaksana PATEN.

4. Perlu dilakukan monitoring dan evaluasi secara berkala untuk peningkatan kualitas pelaksanaan PATEN.

\section{UCAPAN TERIMA KASIH}

Penulis menyampaikan ucapan terima kasih kepada pejabat yang terlibat dalam pelaksanaan kecamatan pilot project PATEN di Kota Padang yang telah membantu penulis dalam memberikan informasi tentang pelaksanaan PATEN. Ucapan terima kasih juga penulis sampaikan kepada Prof. DR. Carunia Firdausy, yang telah memberikan bimbingan dan arahan dalam penyusunan KTI ini.

\section{DAFTAR PUSTAKA}

Dewi, Far'ah Nadia Prasetya. 2014. Implementasi kebijakan Permendagri Nomor 4 ttg Paten (Studi Kasus Di Kantor Kecamatan Temanggung) Skripsi. UMY;

Eko, Fajar Rizki J; Mardiyono; Nurani, Farida.2014. Analisis Kualitas Implementasi Pelayanan Administrasi Terpadu kecamatan http://download.portalgaruda.org/, diakses tanggal 18 oktober 2015);

Edward III, George C. 1980 Implementing Publik Policy, Washington. Congresinal Quaterly Press;

Lanti, Yuniar.2014. Implementasi Kebijakan Pelayanan E-KTP Di Kecamatan Singkil Kota Manado. (http://ejournal.unsrat.ac.id/, diakses tanggal 14 Oktober 2015);

Gubernur luncurkan PATEN pertama di Kota Padang, 2014 (http://www.koran padek.co.id : diakses tanggal 14 Oktober 2015;

Gurning, Desman Armando, 2013. Implementasi Kebijakan Pelayanan Administrasi Terpadu Kecamatan (PATEN) di Kabupaten SIAK, Tesis. Fisipol -UI;

Kemendagri. 2015. Press Release Rapatrapat Hasil-hasil Pembangunan bidang Pemerintahan Umum. 
Jakarta, 12 Februari 2015;

Miranti, Andhina Putri.2015. Studi Eksploratif tentang Faktor Penentu Keberhasilan Implementasi Program Pelayanan Administrasi Terpadu Kecamatan di Kecamatan Sukodono Kabupaten Sidoarjo. Jurnal Kebijakan Publik dan Manajemen Publik Vol.3 Nomor 3 September-Desember 2015; Muhdad, Norman, 2008. Panduan Pelayanan Administrasi Terpadu Kecamatan, Direktorat Jenderal Pemerintahan Umum Depdagri;

Ombudsman RI. 2015. Laporan Tahunan Ombudsman RI;

Peraturan Menteri Dalam Negeri Nomor 4
Tahun 2010 tentang Pedoman Pelaksanaan Administrasi Terpadu Kecamatan;

Savitri, Rina. 2015. Pelaksanaan Pelayanan Administrasi TErpadu Kecamatan (PATEN) di Kecamatan Siak (Studi Kasus Pelayanan Non Perizinan). Jom FISIP Volume 2 No.2 Oktober 2015;

Terry, George R.1986. Dasar-dasar Manajemen. Bandung: Alumni;

Wasistiono, Sadu. 2013. Selekta Manajemen Pemerintah Daerah. Bandung: CV. Fokus Media; 
